\title{
Zastosowanie naturalnej luminescencji do oceny jakości węgla kamiennego
}

\begin{abstract}
Streszczenie. W pracy podjęto próbę określenia możliwości wykorzystania zjawiska naturalnej luminescencji materii do oceny jakości węgla kamiennego. Do eksperymentu użyto stacji pomiarowej wyposażonej w fotopowielacz do identyfikacji fotonów emitowanych przez optycznie wzbudzoną materię. Proces pomiaru liczby emitowanych fotonów przeprowadzono automatycznie, z użyciem środowiska programistycznego LabView. Odnotowano różnicę w liczbie fotonów w wybranym sortymencie węgla. Zaobserwowano, że istnieje praktyczna możliwość różnicowania sortymentu węgla kamiennego pod względem poziomów emisji fotonów.
\end{abstract}

Abstract. The research attempts to determine the possibility of using the phenomenon of natural luminescence of matter to evaluate the quality of coal. For the experiment, a measuring station equipped with a photomultiplier was used to identify photons emitted by optically piqued matter. The process of measuring the number of photons emitted was performed automatically, to which the LabView programming environment was used. There was a difference in the number of photons within the tested groups of coal. It has been observed that there is a practical possibility of differentiating matter in terms of photone emission levels. (The use of natural luminescence to assess the quality of coal).

Słowa kluczowe: fotony, luminescencja, węgiel, jakość

Keywords: photons, luminescence, coal, quality

Złoża węgla kamiennego powstają podczas kompresji przebudowy częściowo zmineralizowanych złóż torfu. Transformacja torfu do węgla kamiennego najczęściej przebiega w dwóch etapach, zwanych odpowiednio etapem biochemicznym i fizykochemicznym.

Uwęglanie (czyli powstawanie węgla kamiennego) zawsze poprzedzone jest procesem torfowania, a następnie grafityzacją [1,2]. Takie warunki pojawiają się w złożach torfu [3]. Etap biochemiczny rozpoczyna się po zakończeniu degradacji mikrobiologicznej po pokryciu torfu przez inny materiał lub w procesie przyrostu złoża. Głównymi czynnikami regulującymi przebieg fazy biochemicznej są temperatura, ciśnienie, objętość i czas. Temperaturę uważa się za kluczowy czynnik przy tworzeniu pokładów węgla. Wzrost temperatury przyspiesza reakcje chemiczne podczas uwęglania [2]-[5]. W miarę postępowania procesów biochemicznych, następuje progresywne uśrednianie i transformacja złoża. Uśrednianie materii rozpoczyna proces fizykochemiczny, w którym ustalają się proporcje węgla w stosunku do tlenu, substancji lotnych i wody - powstaje węgiel brunatny. Kontynuacja zagęszczania przez nadkład powoduje przekształcenie węgla brunatnego w węgiel bitumiczny (miękki), a następnie w węgiel antracytowy (twardy) [6].

Wegiel kamienny jest najpopularniejszym źródłem energii na świecie w ostatnich latach. Pomimo postępujących zmian w sektorze energetyki zawodowe związanej z odnawialnymi źródłami energii, nadal zasila prawie $40 \%$ elektrowni na świecie Węgiel kamienny stanowi jedno z kluczowych paliw dla polskiej i europejskiej gospodarki. Pomimo wdrażania energooszczędnych technologii, zapotrzebowanie na ten surowiec utrzymuje się na stabilnym poziomie. Ze względu na zaostrzające się normy emisji spalin, producenci koncentrują swoją uwagę na dostarczaniu na rynek węgla o wysokiej jakości [7] [10].

Do podstawowych pierwiastków znajdujących się w złożach węgla kamiennego należą węgiel, wodór, azot, siarka i substancje mineralne. Składniki te, odgrywaja ważną rolę $\mathrm{w}$ zachowaniu się paliwa podczas procesów spalania oraz decyduja o jego jakości [11]. Wymagania jakościowe stawiane przez Ministerstwa Środowiska i użytkowników węgla kamiennego zmuszają producentów do wytwarzania sortymentów o ściśle określonych parametrach $[12,13]$. Spełnienie tych wymagań jest możliwe jedynie przy dobrej znajomości parametrów jakościowych eksploatowanych złóż węgla kamiennego. Cechy określające jakość można podzielić na dwie grupy. Pierwsza grupa obejmuje podstawowe charakterystyki węgla - zawartość popiołu, wilgoci, siarki całkowitej. Druga grupa obejmuje parametry charakteryzujące właściwości paliwa w aspekcie jego wykorzystania w technologii. W przypadku energetyki jest to wartość opałowa, zawartość części lotnych, zdolność spiekania, podatność przemiałowa oraz temperatura topliwości popiołu [14] - [18].

F. A. Popp [19] w 1976 roku przedstawił koncepcje, w której założył że każdy czynnik środowiska emituje specyficzne promieniowanie elektromagnetyczne. Do jego obserwacji można wykorzystać długości fali od 300 do 800 $\mathrm{nm}$, przy występowaniu koherentności promieniowania elektromagnetycznego z promieniowaniem wzbudzającym. Pomiar emitowanego promieniowania przez badany materiał przeprowadza się w zakresie światła widzialnego przy zachowaniu czułości widma powyżej $10 \mathrm{~W}$. Wzbudzenia próbki dokonuje się sparametryzowaną wiązką światła, a wysoka czułość pozwala wychwycić fotony. Zaobserwowanie zbioru fotonów w polu magnetycznym o wysokiej częstotliwości może stanowić wskaźnik jakości analizowanego materiału $[20,21]$

Pionierem w zakresie pomiarów promieniowania elektromagnetycznego minerałów kopalnych jest zespół amerykańskich naukowców pracujących pod przewodnictwem L. M. Coyne'a. W swoich badaniach wykazali, że kopaliny potrafią emitować specyficzne promieniowanie elektromagnetyczne w postaci fotonów. Zjawisko to, zwane luminescencją, jest indukowane w minerałach zazwyczaj podczas procesu dehydratacji w temperaturze pokojowej lub podczas łagodnego ogrzewania próbki. Coyne w swoich badaniach mierzył uwolnienie fotonów, które określał jako opóźnioną eksplozję światła widzialnego, która związana jest z napięciem generowanym wewnątrz struktury krystalicznej [22] - [24].

Próbki węgla pozbawione wilgoci wykazują spontaniczna luminescencję. Zjawisko to charakteryzuje się monotonicznym zanikiem aktywności fotonów, które jest poprzedzone ich gwałtownym uwalnianiem. Maksimum 
emisji zostaje osiągnięte zazwyczaj w ciągu kilku pierwszych minut pomiaru. Wielkość aktywności fotonów jest poważnie ograniczona uziarnieniem węgla [25].

W pracy zbadano występowanie zjawiska naturalnej luminescencji węgla kamiennego do oceny jakości węgla kamiennego.

\section{Metodyka badań}

Do badań wykorzystano 8 próbek węgla kamiennego, sortyment miał, pochodzącego z kopalni zlokalizowanej w Górnośląskim Zagłębiu Węglowym. Przed badaniem, próbka została przesiana do postaci produkcyjnej zgodnie $z$ PN-G 04502:2014-11. W próbkach węgla oznaczono zawartość siarki w stanie roboczym metodą Eschki wg PNISO 334:1997, popiołu w stanie roboczym wg PN-ISO 1171:2002, części lotnych w stanie roboczym wg PN-G 04516:1998 i wartości opałowej w stanie roboczym wg PNISO 1928:2002.

Badanie naturalnej luminescencji próbek wykonano $z$ wykorzystaniem stanowiska badawczego wymuszającego postać strumienia świetlnego o sklasyfikowanej długości fali. Do analizy wykorzystano autorskie stanowisko pomiarowe mierzące promieniowanie elektromagnetyczne emitowane $z$ analizowanego materiału. Do rejestracji sygnału wykorzystano detektory R 1538-13 wyposażone w układ wzmacniający sygnał fotopowielacza. Zadaniem fotopowielacza jest zamiana impulsu świetlnego na sygnał elektryczny kierowany do dyskrymiantora progowego. W dyskryminatorze sygnał elektryczny jest konwertowany na impulsy logiczne przewyższające zadaną amplitudę progową. Sterowanie układem pomiarowym odbywa się za pomocą środowiska LabVIEW 2015 (Rys. 1).

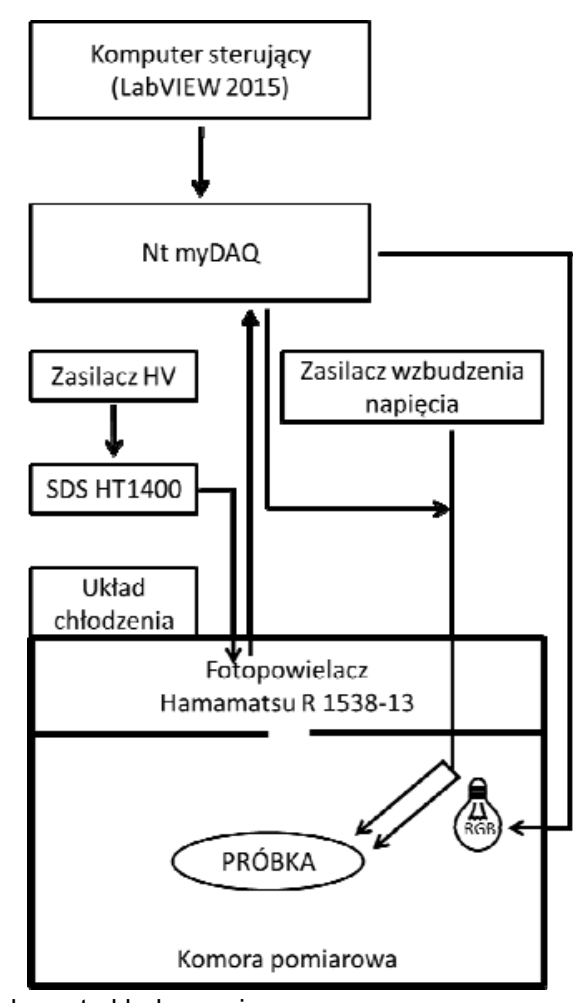

Rys. 1. Schemat układu pomiarowego

\section{Wyniki badań}

Rezultaty przeprowadzonych badań przedstawiono na rysunkach 2-6. Obecność zanieczyszczeń w paliwach (takich jak zawartość siarki i popiołu) decyduje o wielkości emisji zanieczyszczeń podczas procesu spalania paliwa.

Zawartość popiołu informuje o zawartości substancji mineralnej w węglu. Średnia zawartość popiołu w analizowanych próbkach wynosiła $19,09 \% \pm 0,04 \%$ (Rys. 2.). Przeciętna zawartość popiołu w węglu kamiennym w Polsce wynosi $4-16 \%$. Analizowane próbki przekraczają wartości średnich zawartości popiołu. Podwyższona zawartość substancji mineralnej może świadczyć o długotrwałym magazynowaniu węgla na powietrzu i zachodzących procesach powolnego utleniania paliwa lub wydobywaniu paliwa z pokładów gęsto poprzecinanych skałami płonnymi.

Zawartość siarki wskazuje na stopień konwersji katalitycznej paliwa - gdy ta zawartość spada, możemy zaobserwować rosnącą emisję tlenków azotu lub tlenków węgla podczas spalania. Zawartość siarki w analizowanym węglu kamiennym wynosiła $0,47 \% \pm 0,001 \%$ wag. (Rys. 3) i nie odbiega od przeciętnej zawartości tego pierwiastka w polskich węglach kamiennych. Obecność siarki (oraz azotu) wpływa na wartość opałową paliw. Oznaczona zawartość siarki nie wpływa w sposób istotny na zachowanie się paliwa podczas spalania, jednakże w przypadku próbki nr 2 może w połączeniu z para wodna przyspieszać korozję kotła.

Zawartość części lotnych jest podstawową własnością paliw stałych związaną ze stopniem zaawansowania procesów naturalnego uwęglenia (utorfienia, diagenezy, metamorfizmu) lub stopniem odgazowania surowców energetycznych w procesie spalania. Analizowany węgiel kamienny posiadał $37,38 \% \pm 0,08 \%$ substancji lotnych (Rys. 4). Badane próbki odznaczają się podobna zawartością części lotnych, co może świadczyć o ich pochodzeniu z jednego złoża.

Wartość opałowa jest najważniejszą właściwością wszystkich paliw. Ten parametr informuje użytkowników o wartości energetycznej materiału, którą można uzyskać z jednostki masy paliwa podczas całkowitego spalania $w$ atmosferze powietrza. Wartość opałowa analizowanego węgla wyniosła 22951,45 J.g ${ }^{-1} \pm 1177,21 \mathrm{~J} \cdot \mathrm{g}^{-1}$ i nie odbiega od średniej wartości opałowej węgla z polskich kopalni (Rys. 5). Oznaczona wartość opałowa uwzględnia zawartość siarki i popiołu, natomiast nie uwzględnia zawartości wilgoci. Wynika to z faktu, iż próbki przed analizą zostały przeprowadzone $\mathrm{w}$ stan powietrzno-suchy (a więc wszystkie próbki miały tę samą zawartość wody).

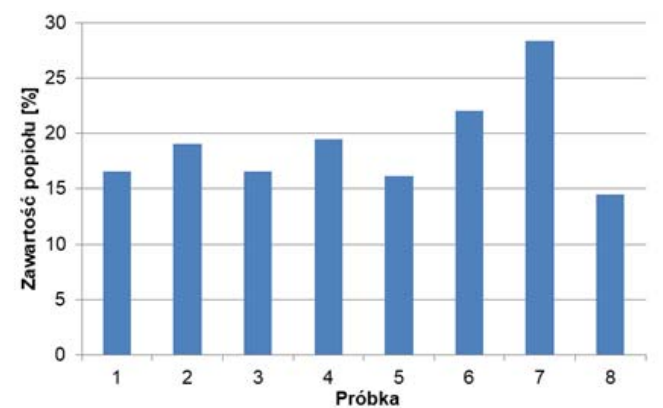

Rys. 2. Zawartość popiołu $\mathrm{w}$ badanych próbkach węgla kamiennego

Węgiel kamienny ze względu na powstawanie z materii organicznej wykazuje tendencję do naturalnej słabej luminescencji $\mathrm{w}$ wyniku pobudzenia sieci krystalicznej promieniowaniem o odpowiedniej energii. Ze względu na czarną barwę, węgiel kamienny może być uważany za ciało doskonale czarne, które pochłania promieniowanie cała swoją powierzchnią. Dzięki zastosowaniu wzbudnika w postaci lampy możliwe jest oszacowanie zmagazynowanej energii w postaci fotonów. Analizowane próbki cechuje duża zmienność uzyskanej emisji fotonów (Rys. 6.). Podwyższona emisja fotonów $z$ analizowanych próbek może wynikać ze zróżnicowania warunków powstawania złóż oraz entropii węgla kamiennego. Obserwowana emisja 
fotonów podczas badań ma charakter ciągły i nie zmienny w czasie pomiaru (Rys. 7). Dla wszystkich analizowanych próbek stwierdzono statystycznie istotne zróżnicowanie emisji fotonów podczas badań. Stwierdzono statystycznie istotną większą liczbę fotonów w próbkach węgla zawierającego większą ilość popiołu i wyższą wartość opałową. Przeprowadzone badania wykazały, że wzrost zawartości siarki w paliwie obniża emisję fotonów.

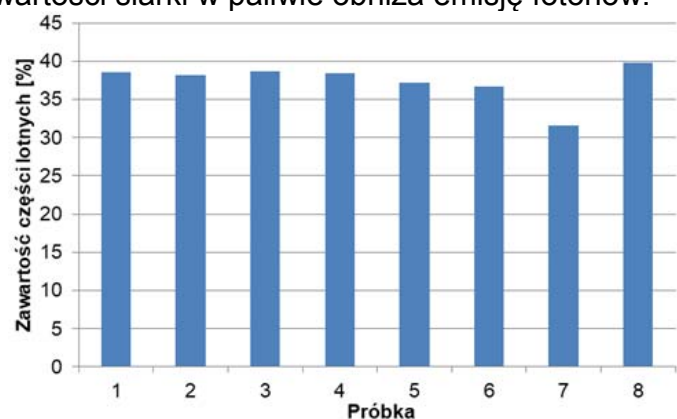

Rys. 3. Zawartość części lotnych $w$ badanych próbkach węgla kamiennego

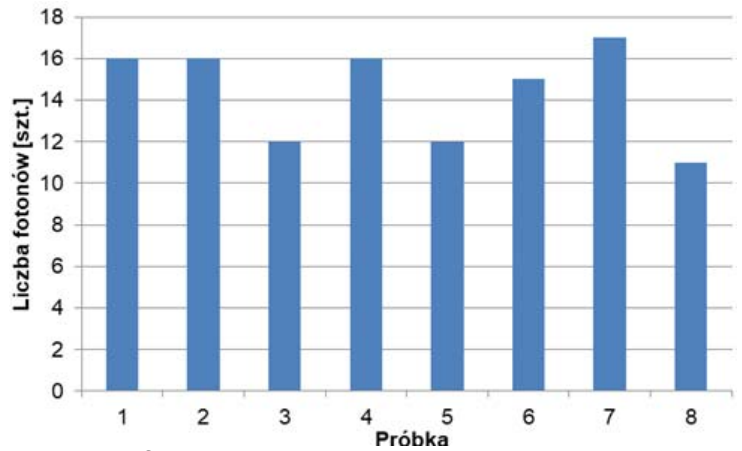

Rys. 4. Emisja fotonów w badanych próbkach węgla kamiennego

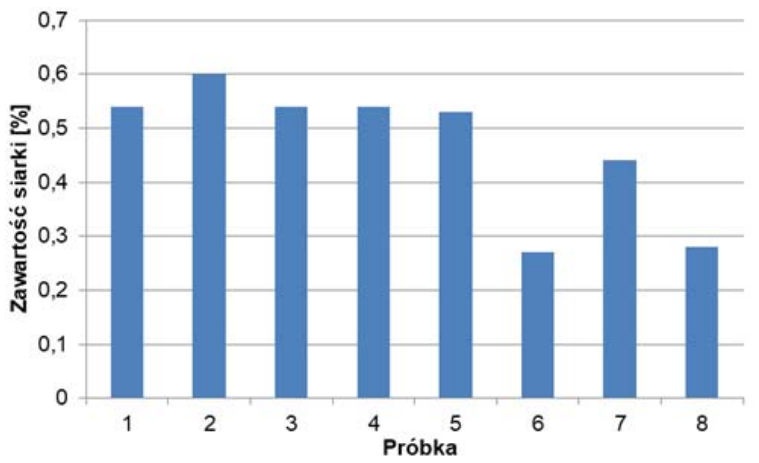

Rys. 5. Zawartość siarki w badanych próbkach węgla kamiennego

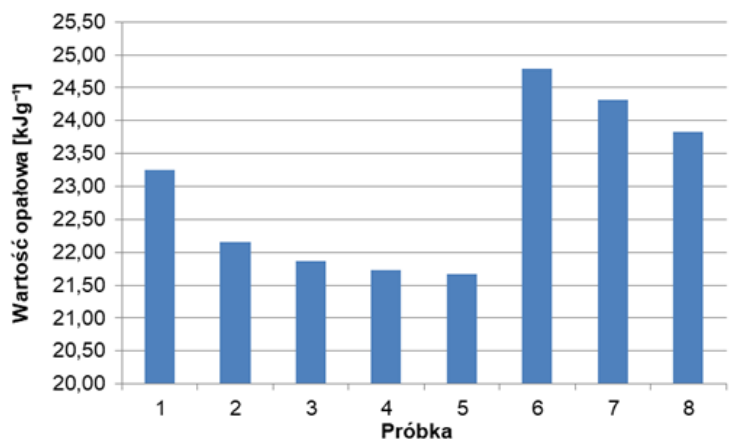

Rys. 6. Wartość opałowa badanych próbek węgla kamiennego

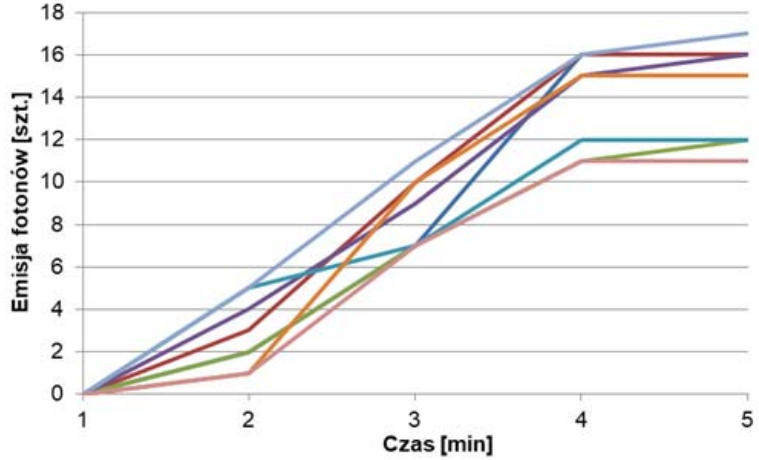

Rys. 7. Przebieg emisji fotonów w badanych próbkach węgla kamiennego w czasie

\section{Podsumowanie}

Przedstawiona metoda wykazała swoją użyteczność do oceny wybranych wskaźników jakościowych węgla kamiennego. Zastosowanie naturalnej luminescencji może być przydatne w szybkim ustalaniu zawartości głównych substancji wpływających na użytkowanie stałych paliw kopalnych. $\mathrm{Na}$ świecie znane są przykłady zastosowań emisji fotonów przez układy żywe m.in. do określania komórek nowotworowych, śledzenia transformacji energii w komórkach, analiz oddziaływania nanocząstek na organizmy [26] - [29].

Występująca monotoniczna emisja fotonów, obserwowana we wszystkich próbach węgla odpowiada obserwacjom przeprowadzonym przez Coyne'a dla kaolinitów (w porównaniu z haloizytem i attapulgitem). Otrzymane wyniki potwierdzają również tezę Coyne'a, że fotony uwolnione $z$ węgla wykazują dużo niższą intensywność niż obserwacje przeprowadzone dla kaolinitu, ale jest to zgodne $z$ wysoce pochłaniającym charakterem węgla. Wyniki uzyskane podczas pomiarów potwierdzaja badania opisane przez Hessley'a [25]. W przeprowadzonych badaniach otrzymano promieniowanie niższe ok. 1000 razy, co może być wywołane niską koncentracją pierwiastków emitujących promieniowanie elektromagnetyczne w analizowanym węglu kamiennym.

Autorzy: dr inż. Maciej Gliniak, Uniwersytet Rolniczy w Krakowie, Wydział Inżynierii Produkcji i Energetyki, Instytut Inżynierii Rolniczej i Informatyki, Al. Mickiewicza 21, 31-120 Kraków, E-mail: maciei.gliniak@urk.edu.pl; dr hab. inż. Jarosław Knaga, Uniwersytet Rolniczy w Krakowie, Wydział Inżynierii Produkcji $i$ Energetyki, Katedra Energetyki i Automatyzacji Procesów Rolniczych, Al. Mickiewicza 21, 31-120 Kraków, E-mail: jaroslaw.knaga@urk.edu.pl; dr inż. Marcin Tomasik, Uniwersytet Rolniczy w Krakowie, Wydział Inżynierii Produkcji i Energetyki, Katedra Energetyki i Automatyzacji Procesów Rolniczych, Al. Mickiewicza 21, 31-120 Kraków, E-mail:

marcin.tomasik@urk.edu.pl; mgr inż. Anna Lis, Uniwersytet Rolniczy w Krakowie, Wydział Inżynierii Produkcji i Energetyki, Instytut Inżynierii Rolniczej i Informatyki, Al. Mickiewicza 21, 31-120 Kraków, E-mail: anna.lis@urk.edu.pl; mgr inż. Ernest Popardowski, Uniwersytet Rolniczy w Krakowie, Wydział Inżynierii Produkcji $i$ Energetyki, Instytut Eksploatacji Maszyn, Ergonomii i Procesów Produkcyjnych, Al. Mickiewicza 21, 31-120 Kraków, E-mail: epopardowski@gmail.com; Matylda Gliniak, Uniwersytet Jagielloński, Collegium Medicum, Wydział Lekarski, ul. św. Anny 12, 31-008 Kraków, E-mail: matylda.gliniak@gmail.com.

\section{LITERATURA}

[1] E. Stach, M. T. M. Mackowsky, G. H. Taylor, A. D. Chandra, R. Teichmüller, Stach's Textbook of Coal Petrology, 3rd edn.Gebrüder Borntraeger, Berlin, 1982, pp. 5-215 (Chapter 2).

[2] G.H. Taylor, M. Teichmuller, A. Davis, C.F.K. Diessel, R. Littke, P. Robert, Organic petrology, Berlin, Gebruder Borntraeger (1998) 6-172 (Chapter 2). 
[3] D. Charman, Peatland and environmental change, John Wiley \& Sons Ltd, England, 2002, pp. 73-91 (Chapter 4).

[4] J. Hower, R.A. Gayer, Mechanism of coal metamorphism, studiesfrom Paleozoic coalfields, Int. J. Coal Geol. 50 (2002) 215-245.

[5] J. Pešek, I. Sy' korová, A review of the timing of coalification in the light of coal seam erosion, clastic dykes and coal clasts, Int. J. Coal Geol. 66 (2006), 13-34.

[6] J.G. Speight, Chemistry and Technology of coal, CRC Press Taylor \& Francis Group, 2013, pp. 101-127 (Chapter 4).

[7] Global Energy Statistical Yearbook, 2016 https://yearbook.enerdata.net/.

[8] L. Thomas, Coal geology, 2nd Ed., John Wiley \& Sons Ltd, England, 2013, pp. 53-86 (Chapter 3)

[9] World Energy Council, World Energy Resources 2013 Survey, Regency House14 Warwick Street London W1B 5LT United Kingdom, 2013, p. 34, (Chapter 1).

[10] Leokadia Róg, Promieniotwórczość naturalna węgli kamiennych i frakcji gęstościowych węgla o zróżnicowanej budowie petrograficznej i chemicznej, Górnictwo i Środowisko 81 Kwartalnik Quarterly 3/2005 81-101

[11] A.R. Papp, W.B. Ayers, D.K. Murray, P.J. Shattuck, Atlas of coal geology, Energy Minerals Division, AAPG, CD-ROM edition, V. 1 coal geology, 1998, Depositional Environments and Sedimentary Geology, coal depositional systems pp 1-6. (Chapter 2).

[12] Róg L. (2003): Wpływ budowy petrograficznej i chemicznej węgla kamiennego na temperaturę topliwości popiołu. Prace naukowe GIG, Górnictwo i Środowisko, kwartalnik nr 1, s. 73-96.

[13] Róg L. (2004): Wpływ parametrów jakościowych na efektywność jego spalania. Materiały z Konferencji na temat „Z węglem kamiennym ekologicznie i oszczędnie", Katowice, GIG s. 5-15.

[14] Lorenz U., Blaschke W., Grudziński Z. (2002): Propozycja nowej formuły sprzedażnej węgla energetycznego przeznaczonego dla energetyki zawodowej. Studia Rozprawy Monografie, nr 112. Kraków, Wydaw. IGSMiE PAN.

[15] Blaschke Z., Blaschke W. (2003): Ocena celowości wzbogacania węgla na potrzeby energetyki w samodzielnych zakladach przeróbczych. Studia, Rozprawy, Monografie, nr 116, Kraków, Wydaw. IGSMiE PAN.

[16] Sztaba K., Blaschke Z. (1996): O podstawowych uwarunkowaniach podnoszenia jakości koncentratów węglowych. Materiały z Konferencji Naukowo-Technicznej: Poprawa jakości węgla w programie dostosowania górnictwa węglowego do warunków gospodarki rynkowej. Prace Naukowe GIG, Seria Konferencje nr 12.

[17] Róg L. (1998): Budowa petrograficzna oraz własności frakcji gęstościowych wydzielonych z węgli kamiennych i antracytu. Prace Naukowe GIG nr 830.

[18] Róg L. (1999): Ocena wpływu zmienności składu petrograficznego na właściwości chemiczno-fizyczne frakcji o różnej gęstości wydzielonych z węgli typów 31.1, 32.2, 33, 34.2, 35.1 i 36. Zeszyty Naukowe Politechniki Śląskiej, Seria: Górnictwo z. 243, s. 111- 126.

[19] Ruth B., Popp F.A. 1976. Experimentelle Untersuchungen zur ultraschwachen Photonenemission biologischer Systeme, Zeitschrift für Naturforschung, 31c, 741-745

[20] Kiełbasa P., Dróżdż T., Nawara P., Dróżdż M. 2017. Wykorzystanie emisji biofotonów do parametryzacji jakościowej produktów spożywczych, Przegląd Elektrotechniczny, 1, 153-156

[21] Oziembłowski M., Dróżdż M., Kiełbasa P., Dróżdż T., Gasiorski A., Nawara P., Tabor S. 2017. Ultra słaba luminescencja (USL) jako potencjalna metoda oceny jakości żywności tradycyjnej, Przegląd Elektrotechniczny, 12, 131134

[22] Coyne L., Lahav N., Lawless J.G. 1981. Dehydration-induced luminescence in clay minerals. Nature, 292, 819-821

[23] Coyne L.M., Lawless J.G., Lahav N., Sutton S., Sweeney M. 1981. Clays as prebiotic photocatalysts origin of life, w: Proc 6th Int. Conf. Int. Soc. for the Study of the Origin of Life (Y. Volman, ed.). Reidel, Dordrecht, Holland, 115-124

[24] Coyne L.M., Pollack G., Kloepping R. 1984. Roomtemperature luminescence from kaolin induced by organic amines, Clays Clay Miner. 32, 58-66

[25] Hessley R.K. 1989. Luminescence in coal and its relation to clay minerals, Clay Minerals, 24, 107-113

[26] Oziembłowski M., Dróżdż M., Kiełbasa P., Dróżdż T., Gąsiorski A., Nawara P., Tabor S. 2017. Ultra słaba luminescencja (USL) jako potencjalna metoda oceny jakości żywności tradycyjnej, Przegląd Elektrotechniczny, 12, 131134

[27] Borc R., Jaśkowska A., Dudziak A., Ultrasłaba emisja fotonowa z układów żywych, (2015), Politechnika Lubelska

[28] Birtic S., Ksas B., Genty B., Mueller M.J., Triantaphylidès C., Havaux M. 2011. Using spontaneous photon emission to image lipid oxidation patterns in plant tissues, Plant Journal, 67, 1103-1115

[29] Hossu M., Ma L., Zou X., Chen W. 2013. Enhancement of biophoton emission of prostate cancer cells by $\mathrm{Ag}$ nanoparticles, Cancer Nanotechnology, 4, 21-26. 